\title{
Facebook, Ritual and Community - Memorialising in Social Media
}

\section{Introduction}

Social networking websites and applications have become the defining factor of online social interaction in the 2010s. Their popularity and addictiveness are based on their ability to convey all aspects of human emotions, from love to hate, from envy to happiness, from humour to sadness, from life to death. However, all social networking sites, especially Facebook (abbreviated FB), have been facing the fact that some of their users have been dying and other people want to use the websites to reminisce about and mourn their loved ones. In a study on virtual memorials conducted already more than a decade ago, communication theorists de Vries and Rutherford argued that online memorials are 'the postmodern opportunity for ritual and remembrance' (2004, 2 ). More recent studies have suggested that the internet 'brings death back into everyday life' (Walter et al. 2011, 295), since death and mourning cultures have undergone significant changes during the 20th century (Ariès1981 [1977], 1974; Pentikäinen 1990; Walter 1994).

In this article, I will examine how commemoration and bereavement rituals (i.e. mourning rituals) are practiced on the Facebook social networking website, ${ }^{1}$ and how they build and maintain existential or spontaneous communitas ${ }^{2}$, the transient personal experience of togetherness, at a time of loss (Turner 1995 [1969], 130-133). By mourning rituals, I am referring to the symbolised manner of communicating bereavement, care, love and affection at a time of loss. They are practices that function as socially approved sym- bols of emotions (Walter 1994, 77), which are intended to keep the community, friends and family of the deceased together at the time of loss (Bell 1992; Sumiala 2010; see also Durkheim 1980 [1912] and van Gennep (1960 [1909]). For example, the Finnish phrase 'I'm sorry for your loss' essentially means 'I take part in your loss', which symbolically refers to a way of taking on some of the grief and sharing the loss together with the bereaved. Flower wreaths, candles and other mementos are also familiar ways of expressing grief, especially at memorials - both online and offline. Mourning rituals in Web environments, however, are mediated by digital multimedia: images, video and text.

The analytical terms existential or spontaneous communitas were coined by ritual theorist and anthropologist Victor Turner (1995, 132-136), who links existential/spontaneous communitas to immediacy and spontaneity, where two individuals experience 'the being of the other' through instant mutuality. In other words, they share an experience that binds them together for a specific amount of time and they actively seek out togetherness from each other during that time. Ritualised communication enhances the experience of communitas and binds people together at a deeper symbolical level.

The research material used for this article was gathered through ethnographical fieldwork and consists of both Finnish and American memorials on Facebook. There are several ways to mourn and honour a loved one on the Web, but here I will focus on the importance of $\mathrm{FB}$ as paving the way for online mourning rituals since it is the only web- 
site that I have been constantly observing since 2007. Digital media, such as FB, enables the articulation of everyday selves and the affordances of sharing care and affection for one another (Giaxoglou 2014, 13), especially at a time of loss.

In the following sections, I will introduce ritual and communitas as theoretical concepts as well as the empirical research material and methods. After that, I will examine how Facebook has been appropriated for mourning and honouring rituals, both from the perspective of users and the service provider. Then, I will continue analysing digitalised rituals and how they convey communitas. Finally, I will discuss the notion of authenticity in Web environments and how it affects the experience of communitas and rituals.

\section{Ritual and communitas (on Facebook)}

In this section, I will briefly reflect upon the notions of ritual and community, both offline and online, in the context of Facebook memorials. A sense of community plays an important role in death rituals - whether they are practiced in either the digital or analogue world. According Turner (1995 [1969], 130-133), ritual is the affirmation community, one which binds it together and strengthens the feeling of togetherness. ${ }^{3}$ Ritual channels communitas (the sense of existential togetherness) and institutionalised social order, and it serves as the arena where social changes (such as death) lead to a new social order (such as widowhood or the dead moving on to the afterlife).

Social media applications, especially Facebook, are designed to thrive on a sense of community, since they create networks of individuals who share the same interests and social relationships together in real-time. Mourning rituals on Facebook manifest themselves in the form of sharing poems and bible quotes, R.I.P. status updates, uploading photos and sharing links to YouTube content (music, mostly) for a memorialised Facebook account, profile group or page. These rituals also consist of offering condolences to the grieving family and regular visits to the memorialised Facebook page or profile, especially during anniversaries and calendar holidays. (Haverinen 2014.) Ritual theorist Catherine Bell highlights, however, that not all communication is necessary ritual; when the core and the aim of the communication is culturally and socially shared ways of expressivity and symbolism (such as how to offer condolences, when and to whom), it is still considered ritualistic (Bell 1992, 73).

According to art researcher Liisa Lindgren, memorials are designed to construct a sense of community and they serve as symbols of collective history as well as symbolical spaces of remembrance (Lindgren 2000, 220). In social media applications, these spatial notions are only reflected at an abstract level, since Facebook as an application is very two dimensional. Nonetheless, Facebook as a space is quite porous and heterogeneous, since it is linked to other Web environments and applications that are shared within and through FB. This porousness is further applied in memorialised spaces, since people share a great amount of external content (i.e. links to videos, images) at memorial spaces.

The feeling of co-presence, speed and accessibility are also factors that differentiate the digital from the analogue. A digital community is often a real-time community, one that binds together a much larger body of people than through in-person communication and also contains extended networks, the people who are not considered the closest of intimates, but who nevertheless are important to keep in contact with via the technology (see also Refslund Christensen \& Sandvik 2013). But most importantly, Web technology creates and enables the feeling of co-presence, especially for those who consider themselves 'always online'. Smart phone technology has brought the internet to our pockets and made it more ubiquitous and portable than ever.

Social media scholar danah boyd (2012, 71) writes that, 'the online is always around the corner. I look up information, multitask by surfing the web, and backchannel with friends. I'm not really online, in that my activities are not centered on the digital bits of the Internet, but I'm not really offline either. I'm where those concepts break down.' boyd also notes that being always-on does not necessarily mean the person is always accessi- 
ble for others $(2012,72)$. This is where the notion of co-presence, sharing imagined spaces, comes in. Social scientist Sherry Turkle has discussed the notion of co-presence as a social and psychological GPS $(2011,67)$, although she criticises it as a means of detaching people from the advantages of in-person communication and of even creating social awkwardness. However, the results of my doctoral study indicate that the feeling of copresence, real-time community, especially for a bereaved individual, is highly empowering, since the individual knows that she or he can always connect with someone in their time of need despite the time and place.

\section{Research material and methods}

The overall research material is derived from my doctoral research conducted in 2007-2014, which consists of three online surveys, 153 survey answers and 38 online interviews, ethnographic observations (both participant and autoethnographic) of several memorial groups and memorialised profiles (both private and public). Only one of the surveys concentrated on Facebook, whereas the others concentrated on mourning online in general as well as on online gaming communities. Nonetheless, many of the answers on the other surveys also reflected on the importance of or else just mentioned Facebook as a place of mourning online.

As mentioned above, the work is also based on long-term ethnography. Ethnographic research on the Web is (currently) called online ethnography (see, e.g. Hine 2015, 2005; Boellstorff et al. 2012), but it also known as netnography (Kozinets 2010) and virtual/digital anthropology (Haverinen 2009; Escobar 1994; Budka 2011). ${ }^{4}$ Ethnography itself is both a method as well as a written description of the people and phenomenon being studied, where the researcher collects data (in this case screenshots and research notes), observes and/or participates intimately in the lives of his or her informants and conducts interviews with respect to the research subject (Geertz 1973). In Web environments, the researcher equally participates and observes the phenome- non in question and aspires to collect a contextually rich set of ethnographic data on what is happening, why, by whom, when and where.

In practice, I have been using Facebook since 2007 on a daily basis for my personal work and until 2014 for research as well. When searching for research material, I used the search function and several Finnish and English keywords ('muistolle', 'in memoriam', 'rip') to find memorial groups and pages. Despite many of them being public and publicly visible, I requested permission from every single of them, and in most cases the permission was declined. Many people declined my research requests since they felt their mourning on Facebook was not 'something for research'. Also, many groups and pages do not realise the full public nature of their content, especially on Facebook, where the user must register first. However, many groups and pages are nevertheless accessible via Google. ${ }^{5}$ (Haverinen 2014; see also Kuula 2011 [2006]; Östman \& Turtiainen 2013.)

Eventually, I observed six Finnish memorial pages and five pages from the United States (in addition to other material derived from the Web). I was also invited to participate in a private memorial group, where I observed how the group functioned as a memorial and resource for peer support. I interviewed the group's founder via email and he also replied to my online survey. In 2008, I had the (unfortunate) opportunity to conduct an autoethnography when one of my Facebook friends committed suicide. After some ethical struggles, and after asking for permission from her family, I decided to analyse my own mourning experience and observed her (later memorialised) Facebook profile as well.

Creating an ethnographic viewpoint for online spaces also requires a deep understanding of the multiple contextualities that each space provides, or, in other words, a certain level of digital nativeness. Anthropologists Tom Boellstorff, Bonnie Nardi, Celia Pearce and T.L. Taylor (2012, 101) describe this approach as textual listening, which is 'unique to online research and requires the understanding of the nuance and conventions of online communication'. In other words, the researcher needs to be able to detect different 
meanings from the languages being used (in this case, Finnish and English) as well as the different aspects of 'net-language', such as the usage of emoticons (Haverinen 2014). Understanding contexts (which in online environments can be overlapping and even contradictory) is crucial when carrying out ethnographic fieldwork. Within this research framework, an understanding of death cultures, customs, rituals and symbols is also of crucial importance when it comes to understanding discourses on death and mourning. ${ }^{6}$

Thus, the material for this particular article has been selected from the above-mentioned repertoire. I will use quotes especially from the survey answers and the in-depth online interviews that I conducted with several of the respondents. Since many of the public memorial group posts can be found via Google, I promised full anonymity to group members if I chose to quote them. I will refer to my interviewees either as anonymised or else by their first names, according to their wishes, and the direct URL's of the memorials will not be disclosed for anonymisation purposes. When taking screenshots, I kept in mind copyright law in both the United States and Finland, which prohibits any commercial use of the material but does allow for non-commercial, scientific and respectful use of it. (FINLEX 2005; Kuula 2011 [2006], 172.) The article focuses on the geographical area of Finland, but the overall research is based in the United States and United Kingdom as well.

\section{Appropriating Facebook for mourning and honouring}

Death breaks a digital connection between people, but the network itself, the application, can maintain the connection in an unbroken and online form, since the data remain within the technology. Facebook realised a few years after its worldwide launch that its users will eventually die and that the remaining intimates of the deceased would mourn and honour their loved one(s) on FB in unforeseen ways, since users at the time were already adapting the application features (such as pages and communities) to enable either private or public memorial groups for reminiscing and sharing stories with one another.

In $2009,{ }^{7}$ Facebook enabled users to request the memorialisation of the profile of a deceased individual, which essentially sets the profile as a dormant account and as a place for remembrance. Before the advent that particular feature, users had been experiencing difficulties with managing departed friends' and family members' profiles, since Facebook is designed to maintain and increase social interaction between its users. However, notifications to contact a departed friend might feel disturbing for the bereaved. Now, a profile can be memorialised with a specific request form, which is sent to Facebook officials to notify them about the passing away of a user and whether the account is set to be a memorial or deactivated. In addition to memorialised profiles, users can create memorial pages and groups as well. A memorial page or group can be created by anyone on Facebook, and they can be set as private (the group can be found by others, but the content is hidden), public (the content is visible to all) or secret (the group is hidden from searches and new members are added only by the administrators of the group) in order to determine who can view the content and who can participate.

These restrictions play a significant role in the way people feel intimacy and create a sense of community, especially when the group's creator sets the visibility of the group as private or secret and personally invites people to attend. A memorialised profile can be viewed by all the friends of the deceased, but new friends and acquaintances cannot send friend requests in order to view the profile. The profile is set as a passive account and $\mathrm{FB}$ avoids referencing it in notifications, tag requests (such as birthday notifications and suggesting photo tagging) or suggestions that people contact that particular person.

Social networking websites enable real-time communication among a large number of people, which is why they are excellent for creating existential communitas immediately after the death of a loved one. People want to connect with others who are experiencing the same grief, and social media provides an immediate channel for such connections. They can share details about the death of their peer, inform others about the 
upcoming memorial service and create a sense of community at a time of loss. People often visit the profile page of the deceased since it is the only common item connecting people with one another. Some people choose, however, to create private and secret Facebook groups for this purpose. In this way, the group's founder can limit what they share, with whom and when without needing to worry about somewhat confusing status update settings.

Reima, a 51-year-old father of two who lost his wife to a sudden stroke, was one of my interviewees who had created a private group to see him through his loss. His wife did not die immediately because of the stroke, but was kept in hospital care for some time. During that time, Reima sought solace from his Facebook network. But he wanted be very specific about the content he shared. One option would have been to limit his status update audience to specific friend groups, but he wanted to have a shared space for all to express their thoughts, especially because he wanted his wife to be able to read the messages during her recovery - or so he hoped.

When I created the page, it was supposed to be just a tool to inform people during the crisis and share information straight from the hospital. I did not want to think about anything else, aside from her later deleting the group as unnecessary after reading all the messages. I also thought it would have been a great way to help her rehabilitate, when she would see all the people caring and supporting her. The role of the forum changed naturally when [she] died. Friends had the opportunity to express their sorrow and condolences. [...] it worked as a commemoration or a greeting card. (Reima, 51 years old, quote anonymised)

Unfortunately, his wife did not survive and the purpose of the support group changed to that of a memorial group. Reima had already had previous experience with mourning on Facebook from a memorial group created for a friend, which is why he knew exactly what kind of space he wanted to create and how he wanting others to participate in remembering his wife. This point was also repeated in several survey answers, where the respondents claimed that witnessing online mourning on Facebook (or elsewhere on the Web) became more acceptable the more they encountered it. Lighting a virtual candle was the most common form of an online mourning ritual ( $80 \%$ of the respondents had lit a virtual candle).

For Reima, creating the group was also an active way to determine what kind of support he wanted to have, for example before and after the funeral. In fact, Reima was very pragmatic about the purpose and stated three different objectives for the group: it was a) a way to inform others and share information, b) a way to help his wife rehabilitate, and eventually, since his wife ultimately passed away, c) a way to express grief and receive condolences (replacing a greeting card).

Facebook memorials are often places for the family of the deceased to inform others about their wellbeing, either directly with the community, or by communicating with the deceased through an imagined dialogue.

The son of my friend died, and the son's FB page worked as a place for paying respects and offering condolences; also the mother participated in the discussion several times. She also wrote on her personal profile constant updates about the loss. Personally, I found this somewhat alien, although I was familiar with online environments, since it would require me to have a 'modern relationship' with the Web, maybe this is a question of personalities, I can share my joy, hide my sorrow. (female, 48 years old, italicised section altered for anonymisation purposes)

I still visit her on her facebook page when I miss her. She's gone, but part of her remains for me (and others) to visit with. (female, 24 years old?)

However, some of the participants in the study reported that they felt strange about the idea of communicating personal grief and intimate feelings, such as hopelessness, in an environment such as FB, which actually contradict the expected codes of conduct. In the same newsfeed, it is possible to read updates about family trips, see selfies and other pictures, advertisements with funny Google translation errors, and in the mid- 
dle of all this daily chatter, an update about a grieving person who misses their loved one. For some, this can feel quite unpleasant. The woman quoted above also states that it is a question of personalities as well: grief is individual. Communities on Facebook - as with other Web environments - are often fragmented and unaware of each other. A person can have connections across the globe and their loved ones might not be aware of the full fabric of their social network.

In a Turnerian sense, Facebook is designed to build and maintain existential or spontaneous communitas, a transient personal experience of togetherness (Turner 1995 [1969], 130-133). It manifests its potential especially at a time of crisis, such as death. However, the way in which one interprets this feeling of togetherness depends on age, gender, the social relationship with the deceased and the extent to which the bereaved is accustomed to online communication, or to having 'a modern relationship with the Web', as in the survey answer quoted above.

I received a request to join the [memorial] group from two of my relatives, my cousin and my cousin's kid (15 years old), and I wanted to join. One reason for wanting to join was that the request from my cousin's child was so moving. How could I refuse? Another reason was that part of our family lives in Sweden and the other part in Finland. This is why it could even be difficult to share thoughts about the passing away of a mutual relative without Facebook. (Salla, 42 years old)

My daughters gained significant help and solace from the FB site dedicated to the boy. This was probably also because they had no other opportunity to connect with people experiencing the same grief since we lived [abroad] and the other people lived in Finland. The texts and expressions of grief by others on the site helped them to move on and gave them permission to grieve and cry. (female, 48 years old?, country anonymised)

Existential communitas enables social cohesion in communities that are experiencing a crisis, and the bereaved has a sense of belonging through the ritualised communication of grief and death: people offering condolences and prayers, sharing memories, links to comforting songs on YouTube, uploading images of angels or other imagery thought to provide solace and hope (teddy bears, flowers, sunsets, etc.). These uploaded materials at the memorial site reveal personal tastes and religious beliefs and the relationship between the uploader and the bereaved as well as the uploader and the deceased. Also, the family of the deceased can have new information about the personality and life of the deceased, about their interests and about relationships they had no knowledge of, such as the number of people affected by the loss. Sharing these stories and content also helps memorialise the relationships, since they are further documented by the application itself.

Facebook's ability to connect different networks of people can sometimes surprise the founders of the memorial, since they often imagine that the people joining the memorial are the ones they also personally know - at least at some level.

I have received a great deal of help and peer support; one knows that one is not alone. Even surprising people have written their condolences; memories, not so much [...]. (Meri, 21 years old)

Initially, the memorial group was intended for close friends only (at least in my own mind), and it was quite a surprise when the member count climbed past 400 , if my memory serves me correctly, in under two weeks. Of course, it somehow feels good when you know that others miss him too. (Mika 24 years old, quote altered for anonymisation)

Although bereavement is experienced individually, it is the community or a sense of community that matters at the time of loss: sharing the loss together. On Facebook, a sense of community and a feeling of co-presence at the time of death are manifested through ritualistic symbols of offering condolences and sharing thoughts and memories of the deceased. They take the form of digitalised versions of offline flower wreaths, memorabilias, a book of condolences and other signs of grief rituals. 
I have received help from the memorial page for my friend on Facebook. Through the page, I have been able to share my feelings and hear about the feelings of others. The song links that have been shared have been very important, partly because in that way will know other people are feeling the same thing. The importance of the memorial group is great for me because it enables me to remember my friend with their* loved ones, although I do not meet them that often. (Nora, 17 years old, quote anonymised since * his/hers in Finnish does not specify gender)

The feeling of co-presence is enabled by smartphone technology as well. One can connect and communicate with their loved ones whenever and where ever regardless of geographic or time distances. Families can live in different countries, such as in the case of Salla quoted above, and share a feeling of togetherness when communicating through an online space - often affiliated with the presence of the deceased, such as their profile page or digital images of them. The profile of the deceased invokes memories, but it also encapsulates the relationship built online. By clicking on the 'See friendship' icon from the profile of a Facebook friend, you can see a list of mutual friends, a timeline of your posts on his/her wall, posts in which either of you have tagged the other, mutual likes (i.e. shared interests and when the Facebook friendship had begun).

\section{Digitalised rituals}

Bringing flowers to the bereaved is a common way of expressing condolences. They are symbols of life, but they are also social and cultural symbols of greeting and affection. Withering flowers are often used as symbols of aging and the end of human life, since the lifespan of flowers is short just as with human life. (Sumiala 2013, 47.) Flowers and plants can be used as memorabilias when, for example, one is planted in memory of someone else, as in the case of Seija, who is quoted below.

[...] for us, a good way to remember [him], in addition to talking about him, has been lighting a candle [in a lantern] by the road at the end of our yard after the memorial event. After the first anniversary of the accident, we will place a candle in the lantern on [his] birthdays, name day and other days that were important to him. With his friend, we also planted his favourites, rugosa roses, in our yard, 15 of them (one for each year we had with him) and a lantern will light [the roses] from morning until night [...]. (Seija, 46 years old, anonymised)

In Web environments, receiving and giving symbols of affection and condolences are mediated in multiple ways. Words are often felt by many to be empty or insufficient for expressing the full meaning of the gesture, which is why many people have invented other ways to express their intentions. Also, social pressure or articulating something, such as condolences, can be heightened in a virtual context, where facial expressions, tones of voice and bodily movements cannot be seen. In the Finnish context, many people have appropriated words familiar from other Web spaces, such as tsemppihali (power hug), jaksuhali (comfort hug), voimia ([I wish you] strength) to express their affection for someone in need. Web communication also enables the use of smileys and other emoticons, ${ }^{8}$ such as a heart symbol $(<3)$. The heart symbol is most frequently used to comment on a post that would be socially inappropriate to 'like'. These words and other symbols are used as a way of ritualised communication, one which affects the way language is used and how different expressions are signified (Bell 1992, 113).

These types of posts and the reactions to them are also visual proofs of communitas. Turner (1995 [1969], 137) has argued that communitas can emerge in unstructured and unpredictable forms, in situations where people share a mutual feeling of togetherness as members of a specific social group - in this case, the friends and family of the deceased. Facebook is designed to emphasise this aspect of communitas, since it notifies others about new comments and likes for a post and it also elevates popular content on the users News Feed, where it can attract more interaction.

Sharing music and images and commenting on the posts of others can be viewed as a ritualized act of solidarity (Walter 1994, 174, 178), where the content being shared acts as symbols of love, memory and affection. They are offered both to 
Image 1. An example from a Finnish memorial group, where one of the group members posted in English (the group and its members were Finnish) and other members responded to the sadness of the post with hearts (screenshot by the author, 9/8/2012, anonymised).

Image 2. Joona drew a picture of a truck on the memorial page for his father (screenshot by the author, 8/9/2011, anonymised).

Image 3. Tuukka shares a link to a YouTube video, to which others comment 'I was just listening to this [song] the other week and it reminded me of [him], beautiful song!' and 'thank you Tuukka!' (screenshot by the author, $8 / 9 / 2011$, anonymised).

Image 4. Susanna provided a link to a Scorpions video entitled 'Send me an Angel' on her sister's memorialised profile. She further commented on her post by saying, 'longing for you surprises all the time all of a sudden' and adding a sad smiley (screenshot by the author, 8/9/2011, anonymised).
Susanna A million words would not bring u back i know because ive tried - but neither would a million tears...i know because ive cried :(

03 May 2010 at 17:10
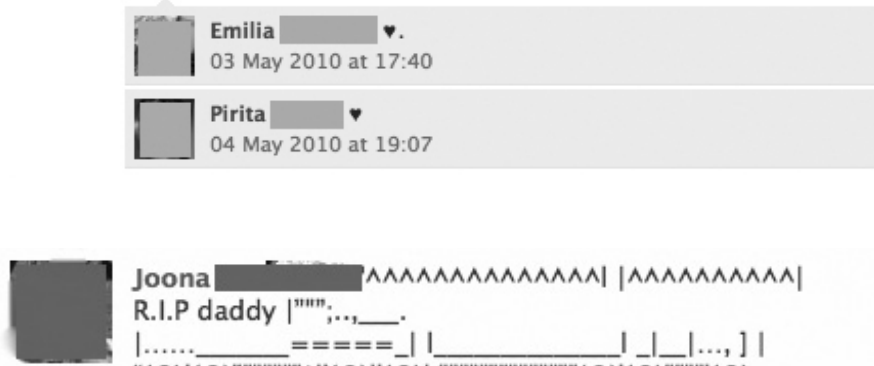

Joona

R.I.P daddy |"m";

|...... $=====$

07 January at 19:23

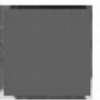

Tuukka http://www.youtube.com/watch?v=J0qNVrnCv

- 5

25 February 2010 at $16: 36$

[C 5 people like this.

Tiia $\quad$ Mä kans kuuntelin tätä biisiä pari viikkoa

sitten ja tuli_ niin mieleen, kaunis biisi!

28 February 2010 at $10: 42$

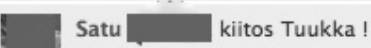

04 June 2010 at 19:39

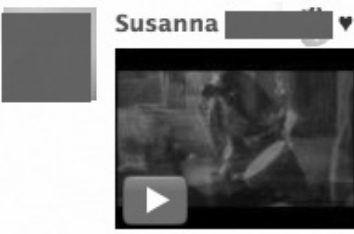

Scorpions - Send Me An Angel

gdata.youtube.com

Music video by Scorpions performing Send Me An Angel.

(C) 1991 The Island Def Jam Music Group

19 April at 10:18. Share

ikävä yllättää aina niin yhtäkkiä :(

19 April at 10:20

the bereaving community as well as to the deceased. Also, joining a memorial group or liking a memorial cause on Facebook are acts of solidarity.

The deceased was not very close to me. Joining the [memorial] group was a gesture to the friends of the deceased. (Petri, 28 years old)

According to sociologist Catherine Bell, ritualisation differentiates sacred and profane acts from each other and gives more importance to the sacred: 'acting ritually is first and foremost a matter of nuanced contrasts and the evocation of strategic, value-laden distinctions' (Bell 1992, 90). Linked content from YouTube becomes ritualised when the context in which such content is being used has to do with remembering, honouring and offering condolences. In this way, ritualised content is symbolically separated from otherwise ordinary content on Facebook.

Linking YouTube videos to a memorialised Facebook account also provides a multi-senso- 
ry experience when viewing the multi-mediated content of audio, text and video. According to Bell, this is the power of ritualisation and ritualistic performance, since the multi-sensory experience provides a sense of being in the situation instead of just 'being told or shown something' (Bell 1997, 160). In this sense, audio and video create a sense of participation, especially in the case of memorial videos. Memorial videos can be a montage of digital images with background music and some text, but often they also contain video footage from different situations where the deceased was alive and well. These videos and images become especially significant for the bereaved, and the online spaces presenting the content become significant places during anniversaries.

According to Johanna Sumiala, these types of videos also create a sense of 'ritual time', which is 'experienced in new, multi-temporal ways' (Sumiala 2013, 87). Videos archive cultural and social norms of the time, which serve as ways of reliving experiences in the present and create a feeling of co-presence for others. Online spaces mediate this experience in multiple ways, since they both store and display the reactions of others as comments, shares and likes. In addition, they also enable a feeling of ritualised togetherness, since they are often viewed during anniversaries or other significant dates.

Facebook wanted to make use of the content provided by its users, and so it created a Look Back video option for users in 2014 as a ten-year anniversary feature. The application creates a video slideshow of users' photos, the most liked and commented on status updates, and other life events, and it even adds background music for it. Friends of a deceased Facebook user can also request a memorial Look Back video; the video can only be viewed by confirmed friends of the deceased (Facebook Help Center 2015). However, this feature did not exist at the time of the survey, which mostly dates back to the years 2010-2011. Some users find the Look Back video to be an emotional experience when witnessing the video montage, if the content is available for the mourners. ${ }^{9}$ For others, it serves as a painful reminder of the death of a loved one. ${ }^{10}$
Despite the negative responses of some FB users, the Look Back video montage was a huge success from the outset; a few months later, in spring of 2015, Facebook announced another memory feature: On This Day. It describes the feature as follows: 'On This Day shows content from this date in the past. For example, you might see past status updates, photos, posts from friends and other things you've shared or been tagged in - from one year ago, two years ago, and so on' (Facebook Newsroom 2015). The feature can be a delight for some, but add a significant amount of negative stress for others.

\section{'But is it real?' Appropriating new modes of mourning rituals}

Online mourning and honouring as cultural practices are currently in the process of being appropriated globally (see, e.g. Fearon 2011; Haverinen 2014; Lagerkvist 2013; Roberts \& Vidal 2000). Despite the increasing number of social media users and online mourners, it is still an alien way for some to remember a loved one and reach out to their community. For these individuals, FB mourning rituals do not enable a sense of existential communitas. Instead, the rituals may even disrupt the mourning experience by creating a disturbing experience with the technology, such as already mentioned with respect to the Look Back feature in the previous section.

Many interviewees discussed the appropriateness of holding online mourning and virtual memorials. ${ }^{11}$ Some claimed that they at first felt that it was inappropriate and strange to mourn someone on Facebook, but others also stated that after experiencing the loss of a loved one themselves, they changed their minds.

At first I felt it was strange, because I believe sorrow and mourning to be an intimate and personal matter. Nowadays, I am more understanding. Yet, I still do not know how I would act when it comes to mourning. Honouring a memory is easier, although dignity and authenticity must be present. Sometimes I have felt that in this case, the Web can also provide a place for performance, which 
is why it has not always felt very correct. (female, 48 years old)

The internet is still a liminal place that is too new to be entirely culturally and socially appropriated as a place for mourning and honouring a loved one. In order to culturally appropriate a new technology, such as the internet, entire social, cultural and communal infrastructures need to change (Suominen 2009, 10). Technology researcher Mika Pantzar (1996) has chosen to use the term 'taming technology' ${ }^{12}$ The term implies that learning to use new technology requires first 'taming' or 'domesticating' it before it can be entirely (socially and culturally) appropriated as something normal, regular and every day. It also implies that the technology being used must equally learn from its users. Web 2.0 represents a specific example of how technology learns from its users, since the development agenda was to make the internet more intuitive, more social and always one step ahead of its users. ${ }^{13}$ The users themselves become producers of content when they mix, recreate and create their own material based on what others have uploaded already in order to create a cumulative social experience. (O’Reilly 2007.)

The aesthetic and symbolical norms of the community also affect the (online) memorial. These norms are not as deterministic and restrictive on the Web as they are offline (for example, who is invited to the funeral service). Nonetheless, since virtual memorials as objects of memorialisation are conceptualised based on previous experiences with mourning and honouring, they also reflect the rituals and behaviours of the offline world. Questions such as who is allowed to grieve, when and where, with whom, and especially how it is displayed for others (see, e.g. Pine 1989, 3; Doka 1989; de Vries \& Rutherford 2004, 7), are only a few of the aspects that affect activity on a memorial site. The greater the number of people participating in the memorial, the more the memorial reflects social norms of appropriateness.

It is important to have good manners. The downside is that internet content is difficult to moderate. Not all have access to it either. Facebook or a virtual memorial brings up good positive memories, but not all people, like the deceased themselves, express real emotions there. (Riitta, 47 years old)

In my opinion, remembering [someone] virtually is not as authentic as lighting a candle in real life or visiting the grave. I think remembering should take some effort. (Nora, 17 years old)

As stated above, the virtual environment itself has an 'unreal' connotation, since it is too easy to click a button or open a webpage. Emotions are also sometimes experienced as 'less real' when mediated from the Web, as Riitta states. In Nora's opinion, there should be some effort in remembering and honouring someone, and merely clicking a virtual candle is thus too effortless to be truly authentic. Are online rituals, then, too 'thin' to be real? The context matters.

The notion of authenticity also extends to how one can express condolences or even practice an online ritual, such as lighting a virtual candle. Writing 'I'm sorry for your loss' is a socially recognised practice, but according to the survey answers, it can sometimes seem empty and meaningless, especially when written in a comment box. In the previous section, I mentioned how people write hearts, musical lyrics and poems on a site and link images and songs in order to provide more content and context when they are offering condolences or communicating with the deceased. These types of content also provide added authenticity precisely because they require more effort than merely writing 'I'm sorry for your loss', but they are also used to add more ritual, more significance, to the message.

Also, the myth of online users that are socially awkward, lonely or otherwise unable to maintain social interaction offline is deeply rooted, especially in Finnish technology discourse.

The Web serves best those who 'do not have anybody' or those who do not know how to talk about their feelings in front of other people. (Taina, 48 years old)

Nowadays, it is perfectly normal and there is nothing wrong with it, as long as the remembering and 
virtual mourning is genuine and does not offend anybody. For many people, the internet is an easier way to express themselves, since the expression of emotions does not matter during the writing [process] and the encouraging support received from others can help a lot, unless the bereaved does not have anyone close to talk to. (Sonja, 18 years old)

As already noted, ritualisation differentiates sacred and profane acts from each other and gives more importance to the sacred (Bell 1992, 91). The interviewees and survey respondents highlighted the importance of 'authentic support', which implies that a person must mean what they write/say online. Otherwise, the division between the sacred and the profane does not exist (although, consequentially, these types of 'authentic gestures' cannot be verified by another person). If the message is considered to be inauthentic by the viewers, it also breaks the existential communitas in the online space. Furthermore, if the person being mourned was personally known to someone or only familiar because of the media (see, e.g. Sumiala 2013), then the appropriateness and authenticity of the mourning process was separated by importance and, as in the following quote, whether it is 'corny' to mourn them or not.

The appropriateness of mourning and honouring depends, in my opinion, on the context; a memorial made for a loved one is touching, but mourning an unknown person (for example, Karoliina Kesti ${ }^{14}$ or the people killed in Norway several years $\mathrm{ago}^{15}$ ) can sometimes be corny. (Anna, [age not disclosed])

Anna in the quote above argues that mourning an unknown person publicly on social media 'can sometimes be corny'. The dictionary definition of corny is 'mawkishly sentimental' (Merriam Webster 2014), which seems to be regarded as undesired and inappropriate behaviour in online environments. However, what is corny to some might be beautifully sentimental to others. Whereas one person might be overcome with emotion, the other, the viewer, does necessarily not read it this way. The Web creates an emotional barrier both in the best and worst sense.
Experiences of authenticity and appropriateness vary, since all spaces - whether online or offline - are intensely contextualised, and experiences are built both a priori and a posteriori (Kant 1997 [1783]; Tilley 1994), or, in other words, both before and after, by referring to previous similar experiences and connecting them to new experiences. Kari describes below how he was asked to take pictures at the funeral of his friend's grandparent, which is a typical Finnish custom; at first, it had felt odd, though, since he did not know the grandparents. But his attitude then changed:

I have photographed one of my friends' grandparents' funeral. [...] The idea of photographing grief first awoke strong feelings inside of me. At first, the instinctive reaction was to be against the whole idea. [...] Recently, I have seen pictures of friends on Facebook, where they stand by the side of a coffin with their loved ones. The publication of such an event on such a networking service made me think about my own opinions. The previous reaction I had [about photographing grief] would have made me assume that I would judge the publication of such photos [as bad], but that didn't happen. (Kari, 29 years old)

There are many social and cultural regulations on how mourning should be expressed and practiced. As a result, many bereaved claim that they feel pressured to fulfil a certain role as a mourner. 'Suffering in silence' is valued highly, especially in Finland, and one should not express strong emotions in front of other people. (Walter 1994, 32-34.) Crying in public is considered distressing and improper, whereas stoic silence is valued as emotional strength. Showing excessive sorrow or 'mourning sickness' (Maddrell 2010, 131) is considered a feminine practice and, as such, distasteful. At the same time, the mourner should cry at least a little to show his/her feelings of loss and despair in order to not appear emotionally cold (Vingerhoets 2013, 131-132).

It was a female neurologist whom I visited in 1986 because of my headaches. Well, she first asked if something particular had happened, since I had more headaches than normal. I told her that 
my husband had passed away recently. Well, she replied that grief must be lived through and that I was good-looking enough to find a new man soon. That was it. (Anne, 56 years old)

Similar situations as the one described above were often reported in the various survey answers: inconsiderate comments, undermining grief and an expectancy that one would soon recover from bereavement were the experiences most often received from others outside the online world. Anne's husband had died only few months earlier and she was expected to recover quickly because she could 'find a new man'. However, she described the peer support received on the Web as healing and helpful since it was possible to communicate with others who were going through the same range of emotions associated with bereavement: disbelief, anger, intense grief and emotional pain. In this case, the internet creates a safe emotional barrier, one which enables the bereaved to feel secure enough to express their emotions to others without the fear being judged.

\section{Conclusion}

In this article, I have analysed how Facebook has been appropriated for these mourning rituals and how the rituals build and maintain a type of existential or spontaneous communitas, the transient personal experience of togetherness, at a time of loss. Existential communitas is deeply linked to immediacy and spontaneity, where individuals feel 'the being of the other' through instant mutuality (Turner 1995 [1969], 132- 36). Current social media applications, especially $\mathrm{FB}$, has been constructed around the idea of communities sharing, caring and being connected to one another more extensively and more in real-time than in comparable offline contexts. FB enables real-time communication by connecting people despite geographical distances, and it has been designed to maintain that sense of connectivity by immediately notifying people about new comments, likes and shares. But what is remarkable and distinctive compared to offline communication is its immediacy and the volume of communication that takes place on Facebook. Communication reaches a vast number of individuals instantly. For a bereaved person, this sense of immediacy with a great number of people who are (often) sharing the same sense of loss is empowering and healing since it creates as sense of community.

When grieving the loss of a loved one, FB becomes a medium for channelling mourning rituals: offering condolences, sharing memories and photos, remembering loved ones during anniversaries. Mourning rituals turn Facebook spaces into meaningful places. They become more than just profile pages or groups; they become shared spaces of care and love. Memorialisations on Facebook are constructed through language and discourse to create an intentional meaning for a digitalised and abstract object and to symbolically represent the honouring of an individual.

In the offline world, mourning rituals often are expressed through material objects, such as photographs, candles, stuffed animals, flower arrangements and even food. On the Web, the expressions are bound to texts, images, audio and video. People share stories about the deceased as well as religious quotes and poems, images, YouTube videos and song lyrics. All of these ways of sharing are intended to serve as ritualised symbols of affection and care, and they make it possible for people to build and maintain existential communitas at a time of loss. Such mourning rituals differ from everyday communication via their symbolical intentions, since they are bound to offline rituals of grief. 'I'm sorry for your loss' is a ritualised phrase for offering one's condolences, but on Facebook it can often be viewed by the entire community of the bereaved, and people can express their condolences in the comment section of the same message. People have also found ways to deal with the problem of expressing the fact that they care without the need for words by writing heart symbols $(<3)$ for the bereaved person. Heart symbols are also used when 'liking' a post or posting a comment would seem inappropriate or somehow incorrect in light of the information being shared.

Appropriateness is also important on Web spaces since death is also linked to the notion of 
honour. A person can join a memorial group out of a sense of honour, as a gesture towards the bereaved. Honour itself is a culturally informed notion of value, one which usually provides a positive status for the individual or community in question. Mourning rituals are carried out because of and in order to honour a person as well as to preserve one's own sense of honour. If you are a family member or otherwise close to the deceased, you are expected to honour the memory of your loved one in one way or another. However, not all people consider mourning on Facebook to be appropriate or honourable, since FB is mostly viewed as an arena for fun and play. Some people also believe that expressing grief or condolences on social media is somehow 'less real', too effortless and inauthentic compared to expressing the same sentiments offline. These sentiments naturally run counter to the sense of communitas created online, since such people believe that a sense of online communitas does not really exist in the context of mourning and honouring a loved one. Further research on this subject is definitely needed and would also help shed light on how people perceive the act of communicating intimate emotions and experiences on social media.

Later in the article I also asked whether or not online rituals are then too 'thin' to be real, since people feel that expressing condolences or grief online is sometimes inappropriate. The answer is that the context matters. If the person is communicating with people that they feel already connected to or who knew their importance in the social network of the deceased, then they will immediately understand the existential feeling of togetherness, of communitas, when witnessing their posts, comments and likes. Mourning is always very subjective and the depth of the emotion is bound to the personality of the individual as well as to their relationship with the deceased and - most importantly - how accustomed the person is to sharing about their life and intimate feelings on social media. The importance of an online memorial is also not static; rather, it changes constantly depending on the technology being used and the way in which grief is being shared (Haverinen 2009, 77; see also Prigerson
\& Jacobs 2001). The bereaved most often reaches out for solace and peer support in the acute phase of loss, but after some time the need for community changes.

Time is, in fact, an interesting notion when it comes to researching online technologies. At the beginning of this research project, in 2007, Facebook had just started to become popular in Finland and the application itself was quite different than what it is today in the year 2015. Existential communitas in this sense is either enabled or disabled by the design processes of social media applications, since they are designed for a specific purpose: to be social. A grieving person often seeks out others and this is why death and mourning rituals are currently becoming increasingly digitalised. People use the applications and websites in unforeseen ways when they want to find a way to memorialise and remember their loved ones through online communities. Since 2004, Facebook has been one of the leaders in paving the way for how people can mourn and honour their loved ones. It is, after all, the most popular global website with 1.5 billion users, and it has been one of the first social media websites to acknowledge the importance of mourning and memorialising a loved one by offering people the option to memorialise a profile or create specific memorial groups. Other social media applications have since followed FB's lead and now offer various ways to memorialise or delete the accounts and materials of deceased individuals.

These developments speak volumes about how death and mourning are being valued and expressed in contemporary society and what people consider to be a socially and culturally appropriate way to communicate grief and honour the memory of a loved one. It is also important to document these processes since they change rapidly and leave no trace of how the websites were previously used. Scholars are also becoming increasingly interested in digital legacies and how to govern the digital material we leave behind. These issues are only a few of the aspects that it would be worthwhile to explore in future research on rituals, bereavement and social media. 


\section{NOTES}

1 Facebook was established in 2004 as a social networking website for students, but it has since grown into the most popular website globally, with a constantly increasing user-base of 1.3 . billion monthly active users in 2014.

2 For Turner (ibid., 132), there are three types of communitas: a) existential or spontaneous communitas, the transient personal experience of togetherness during a specific period of time (such as during a crisis or other atypical event); b) normative communitas, communitas organised into a permanent social system (such as societies and cultures); c) ideological communitas (which can be applied to many utopian social models and to politics).

3 Despite the fact that I highlight the importance of community and communal support, and that the importance of community in rituals is indisputable, expressions of honour and grief on a Web memoria can also be entirely private as well (Haverinen 2014 24). Some people choose to create a privately accessed memorial for their personal coping strategy and as a means of claiming authority in terms of how, where and when they grieve and express their emotions, without the pressure of other people viewing their content.

4 In order to analyse all the research environments, from social media to shared virtual worlds and online gaming environments, from blogs to official memorial websites, I have not aspired to draw conclusions about each particular environment. The results do not indicate that there are substantial differences in the social behaviour and systems of meaning being created in each environment; rather, the differences lie in the details of each website and in what the application in question allows the user to do in the environment. It is not possible to 'like' a status in Second Life, nor is it possible to move an avatar on a blog page, but the social behaviour conducted in these environments is derived from the same motivation: to seek solace at a time of loss.

5 The Association of Internet Researchers (AOIR) has made an extensive step-by-step list for researchers who are determining whether they are or will be conducting ethical research. AOIR also emphasises the possible new technologies and/or new innovations of old technology, which may raise new ethical questions.
Ethical research is, thus, always the responsibility of the researcher, who must continually reflect upon the possible harm of her or his research, how vulnerable the researched community/individual is and the ethicality of his or her research throughout the entire process from data gathering to analysis and final publication. (AOIR 2012, italicising added.)

6 Interestingly, thanatologist Tony Walter has argued that the current death culture is actually more concentrated on expressive talking than ritual itself and that ritual has been replaced by discourse (Walter 1994, 34-35).

7 In 2015, Facebook published a new featured called Legacy Contact, which enables Facebook users to select a trusted 'posthumous' contact who can take control of the deceased person's account and download content, such as photos and status updates, but not private messages. Currently, in March 2015, the feature is available only in the United States. (Guardian 12.2.2015; Facebook 12.2.2015).

8 An emoticon is a visual expression, usually a yellow smiley face, expressing a particular facial expression and feeling, such as anger, amazement, laughter or embarrassment (Frehner 2008).

9 The Daily Dot published an article about the efforts of a father who wanted to gain access to his deceased son's Facebook account in order to see the Look Back video (Hathaway 2014.)

10 For Eric Meyer, the Look Back feature was a painful reminder of the very recent loss of his daughter (Meyer 2014).

11 During my fieldwork in the years 2007-2014, the most negative attitudes and objection was found in Finland, which is due to the differences between death cultures.

12 Also known as domestication; see, e.g. Uotinen 2005.

13 The Google suggestion box is one example, where the program 'guesses' based on the typed word what the next word will be and suggests different combinations of words that are the most likely to be searched.

14 Karoliina Kesti was a teenage Finnish girl who went missing in 2011 and was eventually found dead at a local pond in the city of Tampere. The incident received massive media coverage and several search parties were formed aided by social media. (Wikipedia 2011.)

15 The respondent is referring to the Utoya island massacre in 2011

\section{SOURCES}

All of the interviews and surveys used here were conducted by the author in Finnish and are translated without altering the original message. Respondents have also been anonymised based on their wishes. Permission to use the first name of the respondent was granted during the surveys and interviews.

\section{Email interviews}

Reima, 51 years old, 4/12/2011

Seija, 46 years old, Finland, 9/20/2010

Facebook live chat interview

Anne, 56 years old, 12/15/2010 


\section{Survey answers}

female, 48 years old, 10/26/2010

female, 24 years old, 8/11/2011

Salla, 42 years old, 2/25/2010

Meri, 21 years old, 8/27/2010

Mika, 24 years old, 10/13/2010

Nora, 17 years old, 11/30/2010

Petri, 28 years old, 8/3/2011

woman, 48 years old, 10/26/2010

Riitta, 47 years old, 8/3/2011

Nora, 17 years old, 11/30/2010

Taina, 48 years old, 10/22/2010

Sonja, 18 years old, 11/14/2010

Anna, (age not disclosed), 10/9/2011

Kari, 29 years old, 9/9/2011

\section{Facebook sources}

Facebook 12.2.2015. Adding a Legacy Contact. Facebook Newsroom. http://newsroom.fb.com/news/2015/02/ adding-a-legacy-contact/ [accessed 16.3.2015.]

Facebook Help Center 2015. How can I request a Look Back movie for someone who has passed away? Facebook Help Center. https://www.facebook.com/ help/501833273270804 [accessed 16.3.2015.]

\section{Internet sources}

AOIR 2012. Ethical Decision-Making and Internet Research. Recommendations from the AolR Ethics Working Committee (Version 2.0). AOIR Online Report. http://aoir.org/ reports/ethics2.pdf [accessed 19.3.2015.]

Guardian 12.2.2015. Facebook 'legacy contact' can take over your account when you die. The Guardian. Online. http://www.theguardian.com/technology/2015/feb/12/ facebook-legacy-contact-can-take-over-your-accountwhen-you-die [accessed 16.3.2015.]

Hathaway, Jay 2014. Grieving dad begs Facebook to let him see son's 'Look Back' video. The Daily Dot. http:// www.dailydot.com/news/grieving-dad-sons-facebookvideo-look-back/ [accessed 19.7.2015.]

Merriam Webster 2014. Online Dictionary. http://www. merriam-webster.com/dictionary/corny [accessed 11.1.2014.]

Statista 2014. Number of monthly active Facebook users worldwide. Online statistics website. http://www. statista.com/statistics/264810/number-of-monthly-active-facebook-users-worldwide/ [accessed 6.3.2015].

Wikipedia 2011. Karoliina Kestin katoamistapaus. http:// fi.wikipedia.org/wiki/Karoliina_Kestin_katoamistapaus [accessed 13.4.2015.].

\section{Bibliography}

Ariès, Philippe 1974. Western Attitudes towards Death: From the Middle Ages to the Present. Baltimore: Johns Hopkins University Press.

Ariès, Philippe 1981 [1977]. The Hour of Our Death. New York: Vintage Books.

Bell, Catherine 1997[1992]. Ritual Theory, Ritual Practice. New York: Oxford University Press.
Boellstorff, Tom, Nardi, Bonnie, Pearce, Celia \& Taylor, T.L. 2012. Ethnography and Virtual Worlds: A Handbook of Method. Princeton: Princeton University Press.

boyd, danah 2012. Participating in the Always-On Lifestyle. In Michael Mandiberg (ed.) The Social Media Reader, 71-76. New York: New York University Press.

Budka, Philip 2011. From Cyber to Digital Anthropology to an Anthropology of the Contemporary? Paper at the DGV (German Anthropological Association) conference in Vienna, 14-17 September 2011. http://www.philbu. net/blog/wp-content/uploads/2011/09/budka_dgv_cyberculture_paper3.pdf [accessed 2.2.2014.]

Doka, Kenneth 1989. Disenfranchised Grief: Recognizing Hidden Sorrow. Lexington, MA: Lexington Books.

Durkheim, Émile 1980 [1912]. Uskontoelämän alkeismuodot: australialainen toteemijärjestelmä. Helsinki: Tammi.

Escobar, Arturo 1994. Welcome to Cyberia: Notes on the Anthropology of Cyberculture. Current Anthropology 35 (3), 211-231. http://anthro.vancouver.wsu.edu/media/ Course_files/anth-490-edward-h-hagen/escobar-et-al1994-welcome-to-cyberia-notes-on-the-anthropologyof-cyberculture.pdf [accessed 27.3.2015.]

Fearon, Jordan 2011. The Technology of Grief: Social Networking Sites as a Modern Death Ritual. PhD thesis. England: Antioch University New England. http://rave. ohiolink.edu/etdc/view?acc_num=antioch1307539596 [accessed 27.3.2013.]

FINLEX 2005. Teosten käyttäminen opetuksessa ja tieteellisessä tutkimuksessa. (14.10.2005/821) 14 §. http:// www.finlex.fi/fi/laki/ajantasa/1961/19610404?search \%5Btype\%5D=pika\&search\%5Bpika\%5D=tekijänoik euslaki [accessed 29.5.2012.]

Frehner, Carmen 2008. Email, SMS, MMS: The Linguistic Creativity of Asynchronous Discourse in the New Media Age. Frankfurt am Main: Peter Lang.

Geertz, Clifford 1973. The Interpretation of Cultures. New York: Basic Books.

van Gennep, Arnold 1960[1909]. The Rites of Passage. Chicago/London: University of Chicago Press/Routledge \& Kegan Paul.

Giaxoglou, Korina 2014. "R.I.P. man...u are missed and loved by many": entextualising moments of mourning on a Facebook Rest In Peace group site. Thanatos 3 (1), 10-28. https://thanatosjournal.files.wordpress. com/2012/12/giaxoglou_fb-memorials5.pdf [accessed 22.10.2015.]

Haverinen, Anna 2009. Trobriand-saarilta internetiin antropologisen kenttätyön haasteita virtuaalisessa ympäristössä. Jargonia 7 (16), 1-24. http://urn.fi/ URN:NBN:fi:jyu-201411133247 [accessed 10.3.2012.]

Haverinen, Anna 2011. Bittihautakiviä ja pikselimuistomerkkejä - kuolema- ja sururituaalien virtualisaatio internetissä. Elore 18 (1), 49-70. http://www.elore.fi/ arkisto/1_11/art_haverinen.pdf [accessed 1.4.2015.]

Haverinen, Anna 2014. Memoria Virtualis - death and mourning rituals in online environments. PhD thesis. Turku: University of Turku. http://urn.fi/URN:\%20 ISBN:\%20978-951-29-5773-6 
Hine, Christine 2005. Virtual Methods. Issues in Social Research on the Internet. Oxford: Berg Publications.

Hine, Christine 2015. Ethnography for the Internet: Embedded, Embodied and Everyday. London: Bloomsbury.

Kant, Immanuel 1997 [1783]. Prolegomena: eli Johdatus mihin tahansa metafysiikkaan, joka vastaisuudessa voi käydä tieteestä. Helsinki: Gaudeamus.

Kozinets, Robert 2010. Netnography - Doing Ethnographic Research Online. London: SAGE Publications Ltd.

Kuula, Arja 2011 [2006]. Tutkimusetiikka. Aineistojen hankinta, käyttö ja säilytys. Tampere: Vastapaino.

Lagerkvist, Amanda 2013. New Memory Cultures and Death: Existential Security in the Digital Memory Ecology. The Finnish Death Studies Association, Thanatos 2 (2), 8-24. http://thanatosjournal.files. wordpress.com/2012/12/lagerkvist_newmemorycultures_than2220133.pdf [accessed 11.1.2014.]

Lindgren, Liisa 2000. Monumentum - muistomerkkien aatteita ja aikaa. Helsinki: Suomalaisen Kirjallisuuden Seura.

Maddrell, Avril 2010. Memory, Mourning and Landscape in the Scottish Mountains. In Elizabeth Anderson, Avri Maddrell, Kate McLoughlin \& Alana Vincent (eds.) Memory, Mourning, Landscape, 123-146. New York/ Amsterdam: Rodopi.

Meyer, Eric 2014. My Year Was Tragic. Facebook Ambushed Me With a Painful Reminder. Slate.com. http:// www.slate.com/blogs/future_tense/2014/12/29/facebook_year_in_review_my_tragic_year_was_the_wrong fodder_for_facebook.html [accessed 19.7.2015.]

O'Reilly, Tim 2007. What is Web 2.0: Design Patterns and Business Models for the Next Generation of Software. Communications \& Strategies 1 (17), 17-38. http:// ssrn.com/abstract=1008839 [accessed 19.3.2015.]

Östman, Sari \& Turtiainen, Riikka 2013. Verkkotutkimuksen eettiset haasteet: Armi ja anoreksia. In Salla-Maaria Laaksonen, Janne Matikainen \& Minttu Tikka (eds.) Otteita verkosta. Verkon ja sosiaalisen median tutkimusmenetelmät, 49-67. Tampere: Vastapaino.

Pantzar, Mika 1996. Kuinka teknologia kesytetään: kulutuksen tieteestä kulutuksen taiteeseen. Helsinki: Hanki ja jää.

Pentikäinen, Juha 1990. Suomalaisen lähtö: kirjoituksia pohjoisesta kuolemankulttuurista. Helsinki: Suomalaisen Kirjallisuuden Seura.

Pine, Vanderlyn 1989. Death, Loss, and Disenfranchised Grief. In Kenneth Doka (ed.) Disenfranchised Grief: Recognizing Hidden Sorrow, 13-24. Lexington, MA Lexington Books.
Prigerson, Holly, \& Jacobs, Selby 2001. Traumatic Grief as a Distinct Disorder: A Rationale, Consensus Criteria, and a Preliminary Empirical Test. In Margaret Stroebe, Wolfgang Stroebe, Robert Hansson \& Schut Henk (eds.) Handbook of Bereavement Research, 613-645. Washington, DC: American Psychological Association. Refslund Christensen, Dorthe \& Sandvik, Kjetil 2013. Sharing Death: Conceptions of Time at a Danish Online Memorial Site. In Dorthe Reflslund Christensen \& Rane Willerslev (eds.) Taming Time, Timing Death. Social Technologies and Ritual, 99-118. Farnham: Ashgate.

Roberts, Pamela \& Vidal, Lourdes 2000. Perpetual Care in Cyberspace: A Portrait of Memorials on the Web. OMEGA - Journal of Death and Dying 40 (4), 525-545.

Sumiala, Johanna 2010. Median rituaalit. Johdatus mediaantropologiaan. Tampere: Vastapaino.

Sumiala, Johanna 2013. Media and Ritual. London: Routledge.

Suominen, Jaakko 2009. Johdannoksi: netin kulttuurihistoriaa. In Petri Saarikoski, Jaakko Suominen, Riikka Turtiainen \& Sari Östman (eds.) Funetista Facebookiin. Internetin kulttuurihistoria, 7-22. Helsinki: Gaudeamus.

Tilley, Christopher 1994. A Phenomenology of Landscape: Places, Paths and Monuments. Oxford: Berg.

Turkle, Sherry 2011. Alone together: Why We Expect More from Technology and Less from Each Other. New York: Basic Books.

Turner, Victor 1995 [1969]. The Ritual Process: Structure and Anti-Structure. New York: Aldine Transaction.

Uotinen, Johanna 2005. Merkillinen kone. Informaatioteknologia, kokemus ja kertomus. Joensuu University humanistic publications 40. Joensuu: Joensuu University. Vingerhoets, Ad 2013. Why Only Humans Weep: Unravelling the Mysteries of Tears. Oxford: Oxford University Press.

de Vries, Brian \& Rutherford, Judy 2004. Memorializing Loved Ones on the World Wide Web. Omega - Journal of Death \& Dying 49 (1), 5-26. http://www. ualberta.ca/ jennyy/PDFs/13867811.pdf [accessed 13.2.2014.]

Walter, Tony 1994. The Revival of Death. London: Routledge.

Walter, Tony, Hourizi, Rachid, Moncur, Wendy \& Pitsillides, Stacey 2011. Does the Internet Change how We Die and Mourn? Omega: Journal of Death \& Dying 64 (4), 275-302. https://www.academia.edu/798905/Does_ the_internet_change_how_we_die_and_mourn_A_review_article._2011-12_ [accessed 12.7.2012.]

\section{KEYWORDS}

Facebook, social media, virtual memorials, ritual, communitas, death rituals, bereavemen 